\title{
IDENTIFIKASI FAKTOR PENGARUH DOMINAN KETERLAMBATAN PROYEK AKIBAT RANTAI PASOK PADA PENGADAAN PELAT BETON PRACETAK
}

\author{
Firena Bian' ${ }^{1}$ dan Basuki Anondho \\ ${ }^{1}$ Program Studi Sarjana Teknik Sipil, Universitas Tarumanagara, Jl. Letjen S. Parman No.1 Jakarta \\ firena.325160135@stu.untar.ac.id \\ ${ }^{2}$ Program Studi Sarjana Teknik Sipil, Universitas Tarumanagara, Jl. Letjen S. Parman No.1 Jakarta \\ basukia@ft.untar.ac.id
}

Masuk: 18-07-2020, revisi: 03-08-2020, diterima untuk diterbitkan: 04-08-2020

\begin{abstract}
One way that can be done to speed up the duration of the project is to use precast concrete slabs. However, the use of precast concrete slab elements in the project can be ineffective if in the order stage, production stage, until the delivery stage of precast concrete elements to the project site is not managed properly, which can cause delays in project duration. Therefore, the use of precast concrete slabs is very dependent on the supply chain management. To anticipate this risk, it is necessary to identify what are the dominant factors in the supply chain that affect the procurement of precast concrete slabs which can cause delays in project duration. The initial influence factors were collected through a literature study and interviews with a number of practitioners, followed by a survey using a questionnaire to a number of project actors in projects using precast concrete slabs. The Likert scale 1-5 is used to measure the level of influence of a factor identified on project delays. By using factor analysis techniques, as many as three groups of dominant supply chain factors affecting the procurement of precast concrete slabs were found, namely special factors, technical factors, and human error factors.
\end{abstract}

Keywords: Project Delay; Supply Chain; Precast Concrete Slab

\begin{abstract}
ABSTRAK
Salah satu cara yang dapat dilakukan demi mempercepat durasi proyek adalah menggunakan pelat beton pracetak. Namun, penggunaan elemen pelat beton pracetak di proyek bisa tidak efektif apabila dalam tahap pemesanan, tahap produksi, hingga tahap pengiriman elemen beton pracetak ke lokasi proyek tidak dikelola dengan baik, sehingga dapat menyebabkan keterlambatan durasi proyek. Oleh sebab itu, penggunaan pelat beton pracetak sangat bergantung pada manajemen rantai pasokannya. Untuk mengantisipasi risiko tersebut, perlu adanya identifikasi mengenai faktor dominan apa saja pada rantai pasok yang mempengaruhi pengadaan pelat beton pracetak yang dapat menyebabkan keterlambatan durasi proyek. Faktor pengaruh awal dikumpulkan melalui studi literatur dan wawancara kepada sejumlah praktisi, dilanjutkan dengan survei menggunakan kuesioner kepada sejumlah pelaku proyek di proyek yang menggunakan pelat beton pracetak. Skala Likert 1-5 digunakan untuk mengukur tingkat pengaruh suatu faktor yang diidentifikasi terhadap keterlambatan proyek. Dengan menggunakan teknik analisis faktor, sebanyak tiga kelompok faktor dominan rantai pasok yang berpengaruh pada proses pengadaan pelat beton pracetak ditemukan, yaitu faktor khusus, faktor teknis, dan faktor human error.
\end{abstract}

Kata kunci: Keterlambatan Proyek; Rantai Pasok; Pelat Beton Pracetak

\section{PENDAHULUAN}

Keterlambatan adalah salah satu permasalahan umum yang kerap terjadi di dunia konstruksi bangunan. Keterlambatan proyek merupakan fenomena dimana durasi penyelesaian proyek melampaui tenggat waktu yang telah ditentukan dalam kontrak maupun jadwal rencana. Oleh sebab itu, waktu atau durasi diyakini sebagai salah satu faktor terpenting dalam keberlangsungan proyek konstruksi. Pemilihan metode konstruksi yang tepat merupakan salah satu hal yang dapat dilakukan demi menyelesaikan proyek tepat waktu guna efesiensi pelaksanaan pekerjaan (Jose \& Kumar, 2016). Salah satu metode konstruksi yang dapat dipilih adalah metode beton pracetak. Metode beton pracetak ini dianggap sebagai suatu metode yang dinilai lebih efektif dan lebih unggul jika dibandingkan dengan metode konvesional (Luo et.al. 2018), salah satunya dikarenakan penggunaan metode beton pracetak dapat menghasilkan durasi proyek yang lebih singkat. Hal itu dikarenakan pekerjaan struktur dapat 
Pracetak

dilakukan bersamaan dengan kegiatan produksi beton pracetak di pabrik. Selain itu, beton pracetak dapat terus diproduksi tanpa dipengaruhi oleh faktor cuaca (Steinle et.al. 2019).

Pelat merupakan salah satu elemen konstruksi yang diterapkan pada metode beton pracetak dikarenakan pengecoran pelat dengan metode konvensional memakan waktu yang cukup lama (Wijaya, 2011). Pelat beton pracetak pada dasarnya adalah pelat yang proses pengecorannya dilakukan di suatu tempat terpisah dari lokasi proyek. Di Indonesia sendiri penggunaan metode pelat beton pracetak kini banyak digunakan pada konstruksi gedung bangunan tinggi. Namun, pada kenyataannya penggunaan pelat beton pracetak bisa tidak efektif apabila dalam tahap pemesanan, tahap produksi, hingga tahap pengiriman elemen beton pracetak ke lokasi proyek tidak dikelola dengan baik (Hatmoko et.al. 2019). Oleh sebab itu, pelat beton pracetak sangat bergantung pada manajemen rantai pasokannya. Apabila manajemen rantai pasokan tidak dikelola dengan baik, khususnya dari segi penyediaan elemen pelat beton pracetak di lokasi konstruksi, hal tersebut dapat menyebabkan terjadinya pembengkakan biaya hingga keterlambatan jadwal durasi proyek (Luo et.al. 2020).

Risiko ini tentu tidak dapat dihindari dan harus diantisipasi demi memastikan keberhasilan suatu proyek konstruksi. Sebelum melakukan perhitungan besaran risiko, perlu adanya identifikasi faktor-faktor yang berpengaruh terhadap kegiatan rantai pasok, terutama dari segi pengadaan pelat beton pracetak yang dapat menyebabkan keterlambatan proyek. Beberapa peneliti telah mencoba untuk mengidentifikasi risiko yang terjadi pada proses kegiatan rantai pasok di proyek konstruksi. Hatmoko et.al (2019) berhasil mengidentifikasi 37 faktor pengaruh dari rantai pasok pelat beton pracetak dengan melakukan studi kasus terhadap salah satu perusahaan beton pracetak milik pemerintah. Abedi et.al (2014), mengemukakan bahwa rantai pasokan beton pracetak itu sendiri mengharuskan adanya pertukaran data yang akurat. Sedangkan penelitian yang dilakukan Luo et.al. (2018), menemukan sejumlah faktor yang mempengaruhi kegiatan rantai pasok, salah satunya adalah adanya perubahan desain dan kesalahan dalam pelabelan komponen beton pracetak. Sementara itu, menurut Nissila et.al. (2014), faktor terpenting dalam kegiatan rantai pasok beton pracetak di suatu konstruksi adalah keakuratan informasi antara pemangku kepentingan. Penelitian ini berfokus utnuk mencari faktor dominan dari rantai pasok yang mempengaruhi pengadaan pelat beton pracetak di lokasi proyek yang dapat menyebabkan keterlambatan durasi proyek konstruksi.

\section{Pengertian keterlambatan proyek}

Keterlambatan adalah salah satu permasalahan umum yang kerap terjadi dimana durasi penyelesaian proyek melampaui tenggat waktu yang telah ditentukan dalam kontrak maupun jadwal rencana (Gonzalez et.al. 2013). Akibat dari keterlambatan ini mempengaruhi semua organisasi yang terlibat di dalam proyek. Dalam beberapa kasus, khususnya dari sudut pandang kontraktor, menunda jadwal pekerjaan berarti biaya overhead menjadi lebih tinggi dikarenakan masa kerja yang lebih lama dan adanya kenaikan biaya yang harus dikeluarkan untuk upah tenaga kerja (Shahsavand et.al. 2018). Oleh karena itu, waktu diyakini sebagai parameter paling penting untuk keberlangsungan proyek konstruksi (Chen et.al. 2010). Hal ini yang kemudian menjadi dasar bahwa pemilihan metode konstruksi yang tepat, sangat penting dilakukan demi menyelesaikan proyek tepat waktu (El-Adaway, 2016).

\section{Pengertian rantai pasok pelat beton pracetak}

Risiko yang mempengaruhi kegiatan rantai pasokan telah lama diakui oleh para peneliti sebagai hambatan utama dalam pengiriman/pengadaan barang (Gosling et.al. 2013). Semakin banyak faktor pengaruh yang terkait dengan suatu proses, maka efek negatif berupa waste akan sering terjadi. Selain itu, menurut Soeharto dalam Anondho (2018), semakin banyak kegiatan dan pihak yang terlibat dalam pelaksanaan proyek konstruksi maka dapat menimbulkan permasalahan-permasalahan yang bersifat lebih kompleks. Oleh sebab itu, faktor-faktor yang berpengaruh terhadap kegiatan rantai pasok pelat beton pracetak juga dapat menyebabkan beberapa risiko yang berdampak pada kinerja manufaktur (Hatmoko et.al. 2019). Dalam konstruksi yang menggunakan pelat beton pracetak, berbagai risiko dapat terjadi yang dimulai dari tahap produksi di pabrik hingga pengiriman elemen pelat beton pracetak ke lokasi proyek. Oleh sebab itu, diperlukan penerapan manajemen risiko demi meminimalisir terjadinya risiko pada proyek. Tetapi, sebelum menghitung besaran risiko seperti hal yang telah disebutkan di atas, penelitian ini akan mengidentifikasi faktor-faktor pengaruh dominan rantai pasok yang mempengaruhi pengadaan pelat beton pracetak di lokasi proyek konstruksi.

\section{Identifikasi awal faktor pengaruh rantai pasok pengadaan pelat beton pracetak}

Dalam penelitian ini, beberapa referensi berupa jurnal serta wawancara ke sejumlah praktisi digunakan untuk mencari sejumlah faktor pengaruh dari rantai pasok yang mempengaruhi pengadaan pelat beton pracetak di suatu proyek konstruksi yang dapat menyebabkan keterlambatan durasi proyek yang akan digunakan sebagai faktor awal penelitian. Hasil tabulasi identifikasi awal dapat dilihat pada Tabel 1. 
Tabel 1. Identifikasi awal faktor pengaruh rantai pasok pengadaan pelat beton pracetak

\begin{tabular}{ll}
\hline Kode & \multicolumn{1}{c}{ Faktor Pengaruh } \\
\hline X1 & Salah gambar yang mengakibatkan salah produksi \\
X2 & Birokrasi persetujuan gambar yang terlalu panjang \\
X3 & $\begin{array}{l}\text { Kurangnya perencanaan dalam hal menentukan prioritas area dan } \\
\text { komponen yang akan diproduksi }\end{array}$ \\
X4 & $\begin{array}{l}\text { Cacat produk } \\
\text { X5 }\end{array}$ \\
\end{tabular}

X6 Keterlambatan pembayaran uang muka dari pihak kontraktor ke pabrik

X7 Keterlambatan penerbitan SPK/PO (Purchase Order) ke pabrik

X8 Kurangnya perencanaan penyediaan bahan baku produksi di pabrik (Schedule kedatangan bahan baku)

X9 Ketidaklancaran supply bahan baku dari pemasok ke pabrik

X10 Pengiriman bahan baku ke pabrik tidak sesuai dengan pesanan baik dalam kualitas maupun kuantitas

X11 Kenaikan harga bahan baku di pasaran yang mempengaruhi biaya produksi

X12 Supply bahan baku ke pabrik tersendat terkait pembayaran kepada pemasok kurang lancar

X13 Keterlambatan informasi perubahan gambar ke bagian produksi

X14 Kapasitas produksi di pabrik tidak memadai

X15 Produktivitas tenaga kerja di pabrik rendah

X16 Kompetensi karyawan/tenaga kerja di pabrik kurang

X17 Durasi waktu produksi lama

X18 Kerusakan mesin produksi di pabrik

X19 Kualitas produksi tidak sesuai dengan standar

X20 Perubahan gambar spek/desain

X21 Kesehatan dan keselamatan kerja (K3) di pabrik tidak berjalan

Luo, et al. (2014); Nurcahyo dan Wiguna (2016); Gosling, et al. (2013)

Wawancara

Hatmoko, et al. (2019); Abedi, et al. (2014); Luo, et al. (2018)

Abedi, et al. (2014); Luo, et al. (2018); Nurcahyo dan Wiguna (2016); Gosling, et al. (2013);

Nissila, et al. (2014)

Wawancara

Wawancara

Hatmoko, et al. (2019); Abedi, et al. (2014); Nurcahyo dan Wiguna (2016); Gosling, et al. (2013) \& Wawancara

Hatmoko, et al. (2019); Nurcahyo dan Wiguna (2016); Gosling, et al. (2013) \& Wawancara

Hatmoko, et al. (2019); Nurcahyo dan Wiguna (2016) \& Wawancara

Hatmoko, et al. (2019); Abedi, et al. (2014)

Hatmoko, et al. (2019); Luo, et al. (2018); Nurcahyo dan Wiguna (2016); Gosling, et al. (2013) \& Wawancara

Hatmoko, et al. (2019); Luo, et al. (2018); Gosling, et al. (2013);

Nissila, et al. (2014) \& Wawancara Hatmoko, et al. (2019); Abedi, et al. (2014); Gosling, et al. (2013)

Hatmoko, et al. (2019); Gosling, et al. (2013)

Hatmoko, et al. (2019); Abedi, et al. (2014); Luo, et al. (2018); Gosling, et al. (2013)

Abedi, et al. (2014); Luo, et al. (2018)

Hatmoko, et al. (2019); Abedi, et al. (2014)

Hatmoko, et al. (2019); Luo, et al. (2018); Nurcahyo dan Wiguna (2016)

Hatmoko, et al. (2019); Abedi, et al. (2014); Luo, et al. (2018); Nurcahyo dan Wiguna (2016); Nissila, et al. (2014)

Hatmoko, et al. (2019); Luo, et al. (2018) 
Tabel 1. Identifikasi awal faktor pengaruh rantai pasok pengadaan pelat beton pracetak (lanjutan)

\begin{tabular}{|c|c|c|}
\hline Kode & Faktor Pengaruh & Sumber \\
\hline $\mathrm{X} 22$ & $\begin{array}{l}\text { Cuaca buruk/ bencana alam/ wabah yang mempengaruhi proses } \\
\text { produksi }\end{array}$ & $\begin{array}{l}\text { Hatmoko, et al. (2019); Abedi, et al. } \\
\text { (2014); Luo, et al. (2018) \& } \\
\text { Wawancara }\end{array}$ \\
\hline $\mathrm{X} 23$ & Inventory barang jadi yang kurang baik di gudang pabrik & $\begin{array}{l}\text { Hatmoko, et al. (2019); Nurcahyo } \\
\text { dan Wiguna (2016) \& Wawancara }\end{array}$ \\
\hline $\mathrm{X} 24$ & Tidak adanya pengkodean barang jadi (precast) & Wawancara \\
\hline $\mathrm{X} 25$ & Kesalahan pengkodean di komponen precast & $\begin{array}{l}\text { Luo, et al. (2018); Nissila, et al. } \\
\text { (2014) \& Wawancara }\end{array}$ \\
\hline $\mathrm{X} 26$ & Kesalahan pengiriman komponen precast ke proyek & $\begin{array}{l}\text { Abedi, et al. (2014); Luo, et al. } \\
\text { (2018) \& Wawancara }\end{array}$ \\
\hline $\mathrm{X} 27$ & Kurangnya armada dalam pengiriman precast & Wawancara \\
\hline $\mathrm{X} 28$ & $\begin{array}{l}\text { Keterlambatan pengiriman precast yang diakibatkan oleh salah } \\
\text { kirim }\end{array}$ & Wawancara \\
\hline $\mathrm{X} 29$ & $\begin{array}{l}\text { Keterlambatan pengiriman precast yang diakibatkan oleh } \\
\text { kerusakan kendaraan transportasi }\end{array}$ & Wawancara \\
\hline X30 & $\begin{array}{l}\text { Keterlambatan pengiriman precast yang diakibatkan oleh } \\
\text { kemacetan lalu lintas }\end{array}$ & Wawancara \\
\hline $\mathrm{X} 31$ & $\begin{array}{l}\text { Keterlambatan pengiriman precast yang diakibatkan oleh } \\
\text { kecelakaan lalu lintas }\end{array}$ & Wawancara \\
\hline X32 & $\begin{array}{l}\text { Kegagalan pengiriman precast akibat akses ke lokasi proyek yang } \\
\text { sulit dilalui }\end{array}$ & Wawancara \\
\hline X33 & $\begin{array}{l}\text { Kerusakan precast pada saat loading-unloading di pabrik maupun } \\
\text { di proyek }\end{array}$ & Wawancara \\
\hline X34 & $\begin{array}{l}\text { Kebijakan pemerintah yang terkait dengan pembatasan jam } \\
\text { operasional untuk angkutan berat menuju proyek }\end{array}$ & Wawancara \\
\hline
\end{tabular}

(Sumber: Olahan Penulis, 2020)

\section{METODE PENELITIAN}

\section{Metode pengumpulan data}

Data yang dikumpulkan didapatkan dari kontraktor swasta proyek konstruksi di Jakarta dan sekitarnya yang menerapkan metode pelat beton pracetak pada pelat lantai dengan tipe half slab. Sebelum kuesioner disebarkan perlu adanya validasi kuesioner terhadap sejumlah pakar. Validasi pakar dilakukan untuk memperkuat variabel dalam kuesioner yang akan disebarkan ke responden. Adapun jumlah pakar yang diusulkan berjumlah 5 (lima) orang. Dari hasil validasi pakar diperoleh 15 variabel yang disetujui yang kemudian digunakan sebagai variabel dalam kuesioner. Responden yang menjadi target kueisoner adalah project coordinator, project manager, logistic proyek, dan site engineer.

\section{Metode analisis data}

Analisis data yang digunakan dalam penelitian adalah teknik analisis faktor, yaitu untuk menentukan faktor dominan dengan cara mengidentifikasi hubungan antar sejumlah faktor yang saling independen dengan melakukan uji korelasi. Sebelum analisis faktor dilakukan, perlu adanya validasi untuk menentukan layak atau tidaknya data yang didapatkan. Teknik uji validitas yang akan digunakan adalah korelasi Pearson, yaitu dengan mengkorelasikan skor item dengan skor total item tiap variabel, kemudian pengujian signifikan dilakukan dengan kriteria menggunakan $\mathrm{r}$ tabel pada tingkat signifikan 0,05 dengan uji 2 (dua) sisi (Priyatno, 2019). Kemudian dilanjutkan dengan uji reliabilitas yang bertujuan untuk menentukan tingkat konsistensi dari alat/instrumen pengumpulan data yang dipergunakan. Artinya, apakah alat ukur tersebut akan mendapatkan pengukuran yang tetap konsisten jika pengukuran diulang kembali. Metode yang sering digunakan dalam penelitian untuk mengukur skala rentangan (seperti skala Likert 1-5) adalah Cronbach's Alpha. Setelah itu, data diuji normalitasnya untuk mengetahui apakah data yang dipergunakan terdistribusi normal. Salah satu cara untuk mendeteksi kenormalan data dapat dilakukan dengan teknik Shapiro Wilk. Setelah melalui ketiga uji yang disebutkan barusan, data yang tersisa dan dianggap validlah yang kemudian dipergunakan dalam analisis faktor. Tahapan analisis faktor secara garis besar adalah yang 
pertama melakukan uji korelasi antar variabel asal dengan tujuan agar penyusutan variabel menjadi lebih sederhana. Kemudian menentukan nilai KMO (Kaiser-Meyer-Olkin) dan dilanjutkan dengan menentukan nilai Meaasure of Sampling Adequence (MSA), yaitu kelayakan untuk seluruh variabel yang diobservasi untuk dilakukan analisis faktor. Setelah semua variabel dinyatakan layak untuk analisis faktor, dilanjutkan dengan melakukan ekstrasi faktor berdasarkan kriteria eigen value untuk mendapatkan jumlah faktor yang terbentuk. Metode yang dapat digunakan dalam ekstrasi faktor antara lain adalah Principal Component Analysis. Setelah didapatkan jumlah kelompok faktor dominan yang terbentuk, dilakukan rotasi faktor yang bertujuan agar dapat memperoleh struktur faktor yang lebih sederhana agar mudah diinterpretasikan. Tahap terakhir dari analisis faktor adalah menginterpretasi hasil dari analisis faktor tersebut yang dapat dilakukan dengan mengetahui variabel-variabel yang membentuknya. Analisis data dilakukan dengan bantuan program SPSS.

\section{HASIL DAN PEMBAHASAN}

\section{Validasi pakar}

Dari hasil validasi pakar diperoleh 15 variabel yang disetujui yang kemudian digunakan sebagai variabel dalam kuesioner. Variabel yang didapatkan dari hasil validasi pakar dapat dilihat pada Tabel 2. Adapun jumlah pakar yang diusulkan adalah berjumlah 5 orang.

Tabel 2. Variabel yang disetujui oleh pakar

\begin{tabular}{|c|c|}
\hline Kode & Variabel \\
\hline $\mathrm{X} 1$ & Salah gambar yang mengakibatkan salah produksi \\
\hline $\mathrm{X} 2$ & Birokrasi persetujuan gambar yang terlalu panjang \\
\hline $\mathrm{X} 3$ & Kurangnya perencanaan dalam hal menentukan prioritas area dan komponen yang akan diproduksi \\
\hline $\mathrm{X} 4$ & Cacat produk \\
\hline X5 & Koordinasi lapangan yang buruk antara pemangku kepentingan \\
\hline $\mathrm{X} 7$ & Keterlambatan penerbitan SPK/PO (Purchase Order) ke pabrik \\
\hline $\mathrm{X} 12$ & Supply bahan baku ke pabrik tersendat terkait pembayaran kepada pemasok kurang lancar \\
\hline $\mathrm{X} 13$ & Keterlambatan informasi perubahan gambar ke bagian produksi \\
\hline $\mathrm{X} 18$ & Kerusakan mesin produksi di pabrik \\
\hline $\mathrm{X} 20$ & Perubahan gambar spek/desain \\
\hline $\mathrm{X} 25$ & Kesalahan pengkodean di komponen precast \\
\hline $\mathrm{X} 26$ & Kesalahan pengiriman komponen precast ke proyek \\
\hline $\mathrm{X} 32$ & Kegagalan pengiriman precast akibat akses ke lokasi proyek yang sulit dilalui \\
\hline $\mathrm{X} 33$ & Kerusakan precast pada saat loading-unloading di pabrik maupun di proyek \\
\hline X34 & $\begin{array}{l}\text { Kebijakan pemerintah yang terkait dengan pembatasan jam operasional untuk angkutan berat menuju } \\
\text { proyek }\end{array}$ \\
\hline
\end{tabular}

(Sumber: Olahan Penulis, 2020)

\section{Data kuesioner}

Selanjutnya, kuesioner disebarkan kepada 37 responden yang merupakan pelaku proyek yang saat ini sedang terlibat dalam pembangunan proyek konstruksi dengan metode pelat beton pracetak. Dalam penelitian ini, peneliti berhasil mengumpulkan sebanyak 30 tanggapan responden. Karakteristik posisi responden di proyek tersebut terbagi menjadi seperti Tabel 3 berikut. 
Tabel 3. Karakteristik responden berdasarkan posisi atau jabatan di proyek

\begin{tabular}{cc}
\hline Posisi/Jabatan di Proyek & Jumlah Responden \\
\hline Project Coordinator & 3 \\
Project Manager & 5 \\
Logistik Proyek & 10 \\
Site Engineer & 12 \\
\hline
\end{tabular}

(Sumber: Olahan Penulis, 2020)

Data hasil kuesioner dapat dilihat pada Tabel 4 di bawah ini.

Tabel 4. Data hasil kuesioner

\begin{tabular}{|c|c|c|c|c|c|c|}
\hline \multirow{2}{*}{ Kode } & \multirow{2}{*}{ Daftar Pernyataan } & \multicolumn{5}{|c|}{ Skala } \\
\hline & & 1 & 2 & 3 & 4 & 5 \\
\hline $\mathrm{X} 1$ & Salah gambar yang mengakibatkan salah produksi & 0 & 0 & 2 & 4 & 24 \\
\hline $\mathrm{X} 2$ & Birokrasi persetujuan gambar yang terlalu panjang & 0 & 1 & 3 & 14 & 12 \\
\hline $\mathrm{X} 3$ & $\begin{array}{l}\text { Kurangnya perencanaan dalam hal menentukan prioritas area dan } \\
\text { komponen yang akan diproduksi }\end{array}$ & 0 & 0 & 4 & 11 & 15 \\
\hline $\mathrm{X} 4$ & Cacat produk & 0 & 1 & 3 & 12 & 14 \\
\hline X5 & Koordinasi lapangan yang buruk antara pemangku kepentingan & 0 & 0 & 4 & 16 & 10 \\
\hline $\mathrm{X} 7$ & Keterlambatan penerbitan SPK/PO (Purchase Order) ke pabrik & 1 & 1 & 7 & 9 & 12 \\
\hline $\mathrm{X} 12$ & $\begin{array}{l}\text { Supply bahan baku ke pabrik tersendat terkait pembayaran kepada } \\
\text { pemasok kurang lancar }\end{array}$ & 0 & 0 & 3 & 17 & 10 \\
\hline $\mathrm{X} 13$ & Keterlambatan informasi perubahan gambar ke bagian produksi & 0 & 0 & 3 & 11 & 16 \\
\hline $\mathrm{X} 18$ & Kerusakan mesin produksi di pabrik & 0 & 1 & 2 & 7 & 20 \\
\hline $\mathrm{X} 20$ & Perubahan gambar spek/desain & 0 & 2 & 5 & 14 & 9 \\
\hline $\mathrm{X} 25$ & Kesalahan pengkodean di komponen precast & 0 & 1 & 9 & 8 & 12 \\
\hline $\mathrm{X} 26$ & Kesalahan pengiriman komponen precast ke proyek & 0 & 0 & 7 & 10 & 13 \\
\hline $\mathrm{X} 32$ & $\begin{array}{l}\text { Kegagalan pengiriman precast akibat akses ke lokasi proyek yang sulit } \\
\text { dilalui }\end{array}$ & 1 & 1 & 7 & 10 & 11 \\
\hline $\mathrm{X} 33$ & $\begin{array}{l}\text { Kerusakan precast pada saat loading-unloading di pabrik maupun di } \\
\text { proyek }\end{array}$ & 0 & 2 & 7 & 9 & 12 \\
\hline X34 & $\begin{array}{l}\text { Kebijakan pemerintah yang terkait dengan pembatasan jam operasional } \\
\text { untuk angkutan berat menuju proyek }\end{array}$ & 1 & 5 & 8 & 7 & 9 \\
\hline
\end{tabular}

(Sumber: Olahan Penulis, 2020)

\section{Uji validitas, uji reliabilitas, dan uji normalitas}

Uji validitas dilakukan dengan metode bivariate. Variabel akan dinyakan valid apabila nilai pearson correlation atau $r$ hitung pada suatu variabel lebih besar daripada nilai $r$ product moment dari tabel. Data sampel yang digunakan dalam penelitian ini adalah $30(\mathrm{~N}=30)$ dan taraf signifikansi yang digunakan sebesar 5\%, maka dengan melihat tabel 
nilai $\mathrm{r}$ product moment diperoleh nilai $\mathrm{r}$ sebesar 0,361 . Kemudian $\mathrm{r}$ hitung diperoleh dengan menggunakan software SPSS. Hasil uji validitas dapat dilihat pada Tabel 5 berikut.

Tabel 5. Data hasil kuesioner

\begin{tabular}{cccc}
\hline Variabel & Pearson Correlation & Syarat $\mathrm{r}$ tabel & Keterangan \\
\hline X1 & 0,404 & 0,361 & VALID \\
X2 & 0,359 & 0,361 & TIDAK VALID \\
X3 & 0,635 & 0,361 & VALID \\
X4 & 0,538 & 0,361 & VALID \\
X5 & 0,340 & 0,361 & TIDAK VALID \\
X7 & 0,670 & 0,361 & VALID \\
X12 & 0,599 & 0,361 & VALID \\
X13 & 0,380 & 0,361 & VALID \\
X18 & 0,615 & 0,361 & VALID \\
X20 & 0,771 & 0,361 & VALID \\
X25 & 0,764 & 0,361 & VALID \\
X26 & 0,620 & 0,361 & VALID \\
X32 & 0,654 & 0,361 & VALID \\
X33 & 0,764 & 0,361 & VALID \\
X34 & 0,600 & 0,361 & VALID \\
\hline
\end{tabular}

(Sumber: Olahan Penulis, 2020)

Variabel yang tidak valid dihilangkan dari proses analisis. Dari hasil uji validitas tersebut didapatkan variabel X2 dan X5 tidak memenuhi nilai syarat $r$ tabel. Selanjutnya, uji reliabilitas untuk 13 variabel digunakan untuk menentukan reliabel atau tidaknya suatu instrumen penelitian dengan menghitung nilai koefisien Cronbach's Alpha. Dari hasil analisis didapatkan nilai Cronbach's Alpha sebesar 0,871 sehingga instrumen pengumpulan data (kuesioner) dapat dikatakan reliabel $(>0,6)$. Setelah uji reliabilitas, dilakukan uji normalitas dan didapatkan hasil nilai signifikansi sebesar 0,268 sehingga data dapat dikatakan terdistribusi normal $(>0,05)$.

\section{Analisis faktor}

Setelah melakukan uji validitas, reliabilitas, dan normalitas, selanjutnya dilakukan analisis faktor terhadap 13 variabel yang valid. Hasil analisis faktor yang ditampilkan hanya hasil yang tidak memenuhi asumsi dan siklus terakhir dari analisis faktor. Pada uji MSA terhadap 13 variabel, diketahui bahwa nilai Anti image correlation untuk variabel X4 dan X13 adalah sebesar 0,487 dan 0,404 yang mana kurang dari 0,5 $(<0,5)$. Hasil uji MSA dapat dilihat pada Tabel 6 berikut. 
Tabel 6. Data hasil kuesioner

\begin{tabular}{cc}
\hline Variabel & Anti-image Correlation \\
\hline X1 & 0,749 \\
X3 & 0,685 \\
X4 & 0,487 \\
X7 & 0,543 \\
X12 & 0,851 \\
X13 & 0,404 \\
X18 & 0,543 \\
X20 & 0,616 \\
X25 & 0,759 \\
X26 & 0,518 \\
X32 & 0,725 \\
X33 & 0,714 \\
X34 & 0,811 \\
\hline &
\end{tabular}

(Sumber: Olahan Penulis, 2020)

Maka dilakukan pengujian ulang analisis faktor dengan menghilangkan variabel X4 dan X13. Pada hasil uji MSA yang kedua, diketahui dari 11 variabel, semua memiliki nilai Anti Image Correlation lebih besar dari 0,5 maka uji analisis faktor dapat di lanjutkan. Pada tahap ekstraksi, didapatkan nilai extraction dari setiap variabel uji adalah lebih besar dari 0,5. Maka dapat disimpulkan semua variabel yang diteliti dapat dipakai menjelaskan faktor (11 variabel). Dari hasil initial eigen value menunjukan ada 3 kelompok faktor dominan yang akan terbentuk, yaitu faktor 1, 2, dan 3. Nilai eigen value dari setiap komponen dapat dilihat pada Gambar 1 di bawah ini.

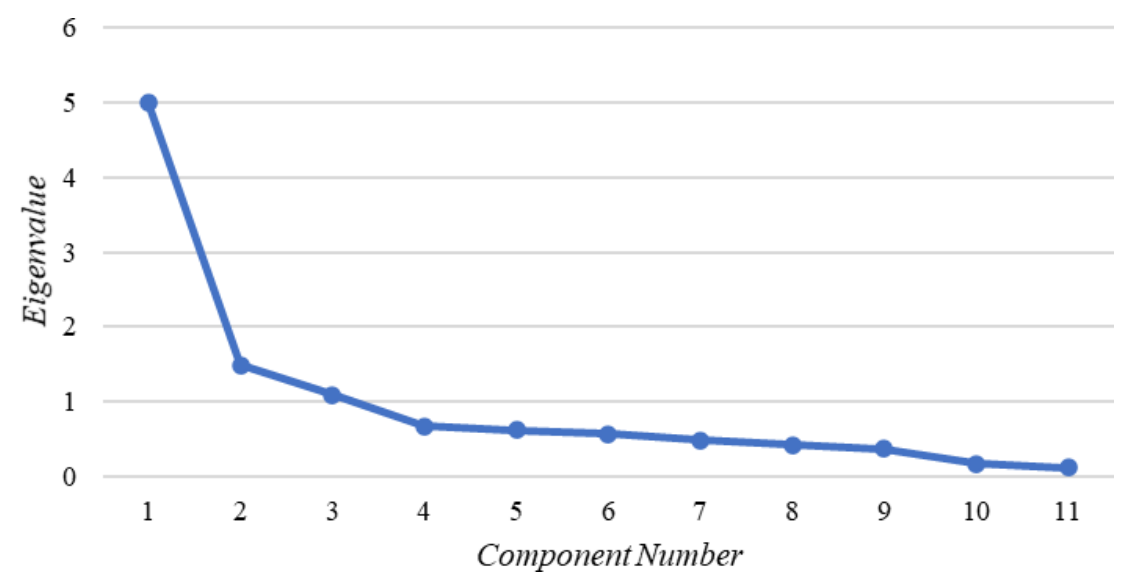

Gambar 1. Scree plot (Sumber: Olahan Penulis, 2020)

Dengan besar variansi yang bisa diterangkan oleh faktor 1 adalah 45,452\%, oleh faktor 2 sebesar 13,561\%, dan oleh faktor 3 sebesar 9,921\%. Total ketiga faktor tersebut akan mampu menjelaskan variabel sebesar 68,934\%. Setelah 
mengetahui bahwa jumlah kelompok faktor dominan maksimal yang bisa terbentuk adalah 3 buah faktor, selanjutnya dilakukan penentuan kelompok masing-masing faktor dominan yang akan masuk ke dalam kelompok faktor 1, faktor 2, atau faktor 3. Cara menentukannya adalah dengan melihat tabel rotated komponen matriks pada tabel 7 sebagai berikut.

Tabel 7. Hasil rotated component matrix

\begin{tabular}{cccc}
\hline Component & 1 & 2 & 3 \\
X18 &, 819 &, 186 &, 038 \\
X34 &, 806 &, 032 &, 165 \\
X33 &, 732 &, 239 &, 449 \\
X32 &, 720 &, 202 &, 259 \\
X1 &,- 114 &, 837 &, 103 \\
X20 &, 364 &, 722 &, 317 \\
X3 &, 188 &, 695 &, 214 \\
X7 &, 247 &, 666 &, 251 \\
X12 &, 508 &, 621 &,- 162 \\
X26 &, 113 &, 141 &, 838 \\
X25 &, 297 &, 290 &, 678
\end{tabular}

(Sumber: Olahan Penulis, 2020)

Dalam menentukan input variabel ke faktor tertentu mengikut pada besar korelasi antara variabel dengan setiap kelompok faktor yang terbentuk, yaitu variabel yang memiliki nilai korelasi terhadap kelompok faktor yang paling besar. Dengan demikian maka dapat disimpulkan kelompok faktor beserta faktor-faktor dominan pembentuknya adalah: Kelompok faktor 1, terdiri atas faktor-faktor dominan X18, X32, X33, dan X34. Sementara kelompok faktor 2, terdiri atas faktor-faktor dominan X1, X3, X7, X12, dan X20. Sedangkan kelompok faktor yang ke 3 disusun atas faktor-faktor dominan X25 dan X26.

\section{KESIMPULAN DAN SARAN}

\section{Kesimpulan}

Kelompok faktor dominan yang dapat menimbulkan risiko keterlambatan proyek akibat dari kegiatan rantai pasok pengadaan pelat beton pracetak yang pertama adalah Faktor Khusus yang terdiri dari faktor dominan berupa kerusakan mesin produksi pabrik, kegagalan pengiriman elemen beton pracetak akibat akses ke lokasi proyek yang sulit dilalui, kerusakan elemen beton pracetak pada saat loading-unloading di pabrik maupun di proyek, serta kebijakan pemerintah terkait dengan pembatasan jam operasional untuk angkutan berat menuju proyek. Kelompok faktor dominan yang kedua adalah Faktor Teknis yang terdiri dari faktor-faktor dominan seperti adanya kesalahan gambar sehingga menyebabkan salah produksi beton pracetak, kurangnya perencanaan dalam hal menentukan prioritas area dan komponen yang akan diproduksi, keterlambatan penerbitan SPK/PO ke pabrik, supply bahan baku ke pabrik tersendat terkait pembayaran kepada pemasok yang kurang lancar, serta adanya perubahan gambar spek/desain. Kelompok faktor yang ketiga merupakan faktor Human Error yang terdiri atas faktor-faktor dominan berupa kesalahan pengkodean di komponen beton pracetak dan adanya kesalahan pengiriman komponen beton ke lokasi proyek. Faktor Khusus adalah kelompok faktor yang paling dominan di antara ketiga faktor yang terbentuk karena dapat mempengaruhi sebesar 45,452\% terhadap risiko keterlambatan proyek, dilanjutkan oleh Faktor Teknis dengan persentase 13,361\%, baru kemudian disusul oleh Faktor Human Error dengan nilai 9,921\%. 


\section{Saran}

Hasil penelitian ini dapat dikembangkan dengan cara memperluas perspektif, bukan hanya dari sudut pandang kontraktor, melainkan dapat ditinjau dari sudut pandang pemberi kerja (owner), konsultan, dan pabrikan. Selain itu, penelitian juga dapat dilakukan dengan menggunakan teknik selain analisis faktor untuk mendapatkan faktor-faktor yang dominan. Sementara itu, dari segi faktor pengaruh yang ditinjau dapat diperluas bukan hanya dari faktor yang mempengaruhi pengadaan pelat beton pracetak ke lokasi proyek, melainkan rantai pasok keseluruhan, seperti dari segi mobilitas, segi instalasi beton pracetak di lokasi proyek, serta faktor-faktor lain yang mungkin memiliki keterkaitan antara rantai pasok pelat beton pracetak dengan keterlambatan proyek.

\section{DAFTAR PUSTAKA}

Abedi, Mohammad, et al. "Cloud Computing as a Construction Collaboration Tool for Precast Supply." Jurnal Teknologi (Sciences \& Engineering) (2014).

Anondho, Basuki. "Pengembangan Model Prediksi Durasi Probabilistik Proyek Pembangunan Gedung Bertingkat Tinggi Berbasis Faktor Pengaruh Eksternal Terukur." International Jurnal of Civil Engineering and Technology (2018).

Chen, Ying, Gul E. Okudan and David R. Riley. "Sustainable performance criteria for construction method selection in concrete buildings." Automation in Construction (2010).

El-Adaway, Islam H. Construction Contract Claims, Changes, and Dispute Resolution. Virginia: American Society of Civil Engineers, 2016.

Gonzalez, Pablo, et al. "Analysis of Causes of Delay and Time Performance in Construction Projects." Journal of American Society of Civil Engineers (2013).

Gosling, Jonathan, Mohamed Naim and Denis Towill. "Identifying and Categorizing the Sources of Uncertainty in Construction Supply Chains." American Society of Civil Engineers (2013).

Hatmoko, Jati Utomo Dwi, et al. "Managing Risks of Precast Concrete Supply Chain: A Case Study." MATEC Web of Conferences (2019).

Jose, Vidya and Dr. P. Rajeev Kumar. "Hollow Core Slabs in Construction Industry." International Journal of Innovative Research in Science, Engineering and Technology (2014).

Luo, Lizi, et al. "Stakeholder-Associated Supply Chain Risks and Their Interactions in a Prefabricated Building Project in Hong Kong." Journal of American Society of Civil Engineers (2018).

Luo, Lizi, et al. "Supply Chain Management for Prefabricated Building Projects in Hong Kong." American Society of Civil Engineers (2020).

Nissila, J, et al. "BIM based Schedule Control for Precast Concrete." International Symposium on Automation and Robotics in Construction and Mining (ISARC) (2014).

Nurcahyo, Cahyono and I Putu Wiguna. "Analisis Risiko Rantai Pasok Beton Ready Mix pada Proyek Pembangunan Apartemen di Surabaya." Jurnal Aplikasi Teknik SIpil (2016).

Priyatno, Duwi. SPSS Panduan Mudah Olah Data Bagi Mahasiswa dan Umum. Yogyakarta: Andi, 2019.

Shahsavand, Parvaneh, Akbar Marefat and Majid Parchamijalal. Causes of delays in construction industry and comparative delay analysis techniques. Engineering, Construction and Architectural Management, 2018.

Steinle, Alfred, Hubert Bachmann and Mathias Tillmann. Precast Concrete Structures : Second Edition. Berlin: Wilhelm Ernst \& Sohn, 2019.

Wijaya, Muliadi Halim. "Evaluasi Kinerja Half-Slab Akibat Pembebanan Gravitasi dan Gempa Bumi." (2011). 